\title{
MIRLET7C Pre-miRNA
}

National Cancer Institute

\section{Source}

National Cancer Institute. MIRLET7C Pre-miRNA. NCI Thesaurus. Code C82741.

MIRLET 7C pre-miRNA is an olig onucleotide that is encoded by the human MIRLET 7C gene and has a role in the regulation of gene expression. 